Volume 21 Number 1 June 2021. P. 89-106

https://doi.org/10.30603/au.v21i1.2111

\title{
Da'wah in Multicultural Society; Struggling between Identity, Plurality and Puritanity: an Empirical Study of Cheng Hoo Mosque of Makassar, South Sulawesi
}

\author{
Erwin Jusuf Thaib, Arfan Nusi, Suharti \\ Sultan Amai State Islamic Institute Gorontalo
}

\begin{abstract}
This article focuses on research on the role of the Cheng Hoo Mosque in the multicultural da'wah movement in Makassar City and the challenges it faces. This study uses a qualitative method with a sociological and da'wah approach. The purpose of this paper is to analyze the existence of multicultural da'wah at the Cheng Hoo Mosque in Makassar City and the challenges it faces from aspects of identity, plurality, and puritanity. Data were collected through interviews, field observations, and documentation studies. The research findings show that the Cheng Hoo Mosque is a religious and cultural identity of the Chinese Muslim community in Makassar City. The challenge faced by multicultural da'wah is plurality, especially in the field of religion and religious puritanism which leads to division. The multicultural da'wah movement at Cheng Hoo Mosque is carried out with three approaches, namely non-mazhab mosques, mosques that are open to all groups, across cultures and religions, and acceptance and respect for local culture.
\end{abstract}

Keywords: Cheng Hoo Mosque, Da'wah, Multicultural.

\section{Dakwah dalam Masyarakat Multikultural; Perjuangan antara Identitas, Pluralitas, dan Puritanitas: Kajian Empiris Masjid Cheng Hoo Makassar, Sulawesi Selatan}

\begin{abstract}
Abstrak
Artikel ini fokus pada penelitian tentang peranan Masjid Cheng Hoo dalam gerakan dakwah multikultural di Kota Makassar serta tantangan yang dihadapinya. Penelitian ini menggunakan metode kualitatif dengan pendekatan sosiologi dan dakwah. Data dikumpulkan melalui wawancara, observasi lapangan dan studi dokumentasi. Tujuan tulisan ini menganalisis eksistensi dakwah multicultural di Masjid Cheng Hoo Kota Makassar serta tantangan yang dihadapinya dari aspek identitas, pluralitas dan puritanitas. Temuan penelitian menunjukkan bahwa Masjid Cheng Hoo menjadi identitas religious dan kultural komunitas Tionghoa Muslim di Kota Makassar. Tantangan dakwah multikultural yang dihadapi adalah pluralitas khususnya di bidang agama dan puritanisme agama yang menjurus ke arah perpecahan. Gerakan dakwah multikultural di Masjid Cheng Hoo dilakukan dengan tiga pendekatan yakni masjid non mazhab, masjid yang terbuka untuk semua golongan, lintas budaya dan agama, serta penerimaan dan penghargaan terhadap budaya lokal.
\end{abstract}

Kata Kunci: Masjid Cheng Hoo, dakwah, multikultural.

Author correspondence

Email: erwinjthaib@iaingorontalo.ac.id

_Available online at http://journal.iaingorontalo.ac.id/index.php/au/index 


\section{A. Introduction}

Makassar is a multi-cultural city with residents of various ethnicities. Not only from the native ethnicities of South Sulawesi such as Makassar, Bugis, Mandar, and Toraja but also ethnic groups from outside South Sulawesi such as Papua, Maluku, Java, Kalimantan, Sumatra, Aceh, Gorontalo, Arab, India, and even Chinese. It can be said that the people of Makassar themselves come from various ethnicities, from Sabang to Merauke. ${ }^{1}$

Makassar has long been known as a religious city because the two main tribes that inhabit this city, namely the Bugis and Makassar tribes, are known as devout Muslims, with various other tribes who are Muslim who also inhabit this city. Even so, the religious activities of other religions also continue to run normally without any disturbance. This condition reinforces the position of Makassar City as a multi-cultural city.

As a city inhabited by the vast majority of Muslim people, the dynamics of the Islamic religion are felt in the city of Makassar. In addition to Islamic religious ritual activities, Islamic religious, social activities can be easily found in people's lives in Makassar City, one of which is the da'wah movement. Da'wah Islamiyah is one of the vehicles for the religious development of the Islamic community, which usually takes place in the Muslim community, as is the case in Makassar City.

As a multi-cultural city, the dynamics of Makassar City's community activities adjust to the multi-cultural reality itself. Likewise, da'wah activities must always be able to adapt to the conditions of a multi-cultural society. In a context like this, a multi-cultural da'wah approach is necessary. Multi-cultural da'wah itself has several indicators, including a). recognize and respect the uniqueness and diversity of ethnoreligious, b). recognizes points of commonality in ethnoreligious diversity. ${ }^{2}$ This definition shows two main factors that must be respected, namely diverse religions and cultures.

${ }^{1}$ Reni Juliani, Hafied Cangara, Andi Alimuddin Unde, Komunikasi Antar Budaya Etnis Aceh dan BugisMakassar Melalui Asimilasi Perkawinan di Kota Makassar, dalam Jurnal Komunikasi KAREBA Vol.4 No. 1 Tahun 2015, h.71

2Ilyas Ismail dan Prio Hotman, Filsafat Dakwah, Rekayasa Membangun Agama dan Peradaban Islam (Jakarta: Kencana, 2011), h. 264-267 
Therefore, respect for religious and cultural diversity is an essential aspect of multi-cultural da'wah. The preachers must build an awareness that followers of certain religions live with people of the same religion as them. However, they live with followers of other religions who come from different races and have different cultures. ${ }^{3}$

One of the ethnic groups who live in Makassar is Chinese. The Chinese ethnic groups, which are more engaged in the economic sector in their daily activities, generally adhere to three religions, namely Confucianism, Buddhism, and Christianity. It turns out that there are also Chinese people who are Muslim and actively carry out their religious activities.

Discussing the existence of Chinese Muslims in the city of Makassar cannot be separated from the existence of the Cheng Hoo mosque as a marker of their identity as Muslims. Moreover, the study of the existence of Chinese people in Makassar is also interesting considering that in Makassar City, there have been incidents that depict anti-Chinese sentiments. It is possible that economic and political motives drove this incident at that time. Currently, indications of the strengthening of anti-China sentiment can be felt even though it is still verbal, mainly on social media. In this context, discussing the existence of Chinese Muslims in Makassar City society becomes interesting.

The existence of the Cheng Ho mosque as a basis for religious activities for the Chinese Muslim community. The architecture of the Cheng Hoo mosque, which is very typical of China and the existence of the community itself, is an attraction for the people of Makassar City and visitors from other areas to visit and worship at this mosque. The involvement of non-Chinese people in various religious activities at the Cheng Hoo mosque made religious activities and da'wah at this mosque aimed at all groups, both from various religious organizations and from various ethnic groups, and not only aimed at the Chinese Muslim community. This is an indication of multicultural-based da'wah activities at the Cheng Hoo mosque.

${ }^{3}$ Izzuddin dan Ahmad Kairul Fata, Realizing Religion as The Source of Harmony in a Multi-cultural Society, Kontemplasi: Jurnal Ilmu-ilmu Ushuluddin, 8(02) 2020, h. 177 
However, multicultural-based da'wah activities at the Cheng Hoo mosque did not always run well. Problems that arise in the context of multicultural da'wah always face the main challenges related to the identity of the Chinese themselves, problems related to plurality, and problems related to the religious purification movement in Makassar City. This problem will be the main focus of the study in this article.

This study uses a qualitative method with a sociological and da'wah approach, which will attempt to find descriptive data, a systematic, factual, and accurate description of the facts, properties, and relationships between the observed phenomena. Data were collected through interviews with informants, observation at the research location, and documentation study.

\section{B. Cheng Hoo Mosque: Religious and Cultural Identity}

The existence of the Cheng Hoo Mosque cannot be separated from the existence of Chinese people in Indonesia, including in Makassar. In general, Chinese people are divided into two, namely "totok" and "peranakan," according to Afif, the term "totok" is an ethnic Chinese who is still original, in the sense that it still maintains Chinese culture and avoids mixed marriages with indigenous people even though they have long lived in Indonesia. At the same time, the hybrid is the result of descent from mixed marriages. ${ }^{4}$ According to Afif, some embraced Islam because it was in the form of guidance and then because it was based on the harmony between Islamic teachings and Chinese culture, and some were even caused by disappointment in their teachings, besides that because of the factor of marriage. In general, talking about the identity of Chinese Muslims cannot be separated from the history of the Chinese community as part of Indonesia's history as a whole. ${ }^{5}$

The Cheng Hoo Mosque in Makassar was built to serve as a means of worshiping Allah Almighty. Thus, this mosque does not significantly differ from other mosques built with the same purpose. Because, in essence, all mosque

\footnotetext{
${ }^{4}$ Afthonul Afif, Menjadi Indonesia: Pergulatan Identitas Tionghoa Muslim Indonesia, (Yogyakarta: Parikesit Institute, 2010), h. 167.

${ }^{5}$ Bastian Yunariono, Retno Andriati, The Construction of Chinese Muslims Identities in Surabaya, dalam Walisongo: Jurnal Penelitian Sosial Keagamaan Volume 28 Nomor 1 2020, h.66
} 
buildings, wherever they are, are all the same, namely as a means of worship for Muslims. The existence of a mosque is a necessity for a Muslim community wherever they are. ${ }^{6}$

However, it cannot be denied that the Cheng Hoo Mosque in Makassar City is a new social phenomenon with its distinctive characteristics. The Cheng Hoo Mosque has become a marker of two phenomena at once, namely religion and culture. The name of the name Cheng Hoo as the name of the mosque refers to the name of the Chinese warlord sent to the Nusantara. However, unlike the Chinese commander sent to all corners of the world, Cheng Hoo has the same beliefs as the majority of the population of the Nusantara, namely Islam. ${ }^{7}$ Thus the use of the name Cheng Hoo as the name of the mosque is an affirmation of the religious identity of people of Muslim Chinese descent. ${ }^{8}$ This needs to be emphasized, considering that Chinese people in Makassar and elsewhere are not Muslims. Thus, the existence of Chinese Muslims requires a marker and the Cheng Hoo Mosque is an appropriate marker of religious identity. Identity is born from a social process whose shape is constantly changing over time. ${ }^{9}$ The Chinese Muslim community is a cultural identity originating from China which later evolved into Muslim Chinese in Indonesia.

The Cheng Hoo Mosque has also become a cultural identity for Chinese Muslims. Physically, the shape of the Cheng Hoo Mosque building is different from most mosques. If mosque domes mark many mosque buildings in all regions of the Islamic world, this is not found in the Cheng Hoo Mosque building. The Cheng Hoo Mosque building looks more like a Chinese-style building like a Kelenteng, which is sometimes dominated by red as the

\footnotetext{
${ }^{6}$ Choirul Mahfud, Chinese Muslim Community Development in Contemporary Indonesia: Experiences of PITI in East Java, in Studia Islamika Volume 25 Nomor 3 2018, h. 474-475

${ }^{7}$ Amanda Rizky, Re-Aktualisasi Kisah Perjalanan Laksamana Cheng Hoo di Cirebon Melalui Batik (Kajian Batik di Cirebon serta hubungannya dengan Bahasa Rupa Tradisi, dalam CORAK Jurnal Seni Kriya Volume 8 Nomor 1 2019, h. 31

${ }^{8}$ Rahmawati, et al., Chinese Ways Being a Good Muslim: From The Cheng Hoo Mosque to Islamic Education and Media Literacy, in Indonesian Journal of Islam and Muslim Societies, Volume 8 Nomor 2 2018, h. 231-232

${ }^{9}$ Ahmad Alwajih, The Discourse of Tionghoa Muslim Identity in Indonesia After The Reform Order: A Critical Discourse Analysis of "Komunitas Cheng Hoo" Magazine, Asian Journal of Media and Communication Volume 4 Number 2 2020, p.101
} 
dominant color in Chinese culture. ${ }^{10}$ The identity of the mosque does not appear when referring to the various forms of mosque buildings in the Nusantara. The physical characteristics of the Cheng Hoo Mosque are a distinct cultural marker for the Chinese Muslim community. At least the Cheng Hoo Mosque has become a religious and cultural symbol of the Chinese Muslim community. They emphasized that they embraced Islam but could not be separated from their cultural roots as Chinese people. ${ }^{11}$

The existence of the Cheng Hoo Mosque as a religious and cultural marker of the Chinese Muslim community in Makassar City shows several unique aspects. This phenomenon shows that Islam is a suitable value and can adapt to any cultural identity. Chinese culture is not identical to Islamic values because historically, Chinese culture was not built on the foundation of Islam. However, when these two values meet, a dynamic mixture will emerge that is inseparable from the historical roots of Islamic and Chinese values, as seen in the form of the Cheng Hoo Mosque. However, religion and culture are some of the essential aspects when discussing Chinese Muslim ethnicity. ${ }^{12}$ Moreover, all of that is represented by the existence of the Cheng Hoo Mosque. In addition, the existence of the Cheng Hoo Mosque has enriched the face of Islam in Makassar alongside Islamic values that were traditionally born from areas inhabited by people with a solid Islamic base such as the Bugis and Makassarese.

\section{Plurality and Puritanism: Challenge of Da'wah}

Da'wah is an Islamic religious movement that tends to invite people to do good and leave bad deeds. The da'wah movement has been carried out since the era of the Prophet Muhammad until now. Furthermore, throughout its

\footnotetext{
${ }^{10}$ Dinda Wulan Afriani, Masjid Jami PITI Laksamana Muhammad Cheng Hoo Purbalingga: Simbol Keindahan Toleransi Dalam Akulturasi, dalam IBDA Jurnal Kebudayaan Islam Volume 12 Nomor 1 2014, h.29. Lihat juga Risca Damayanti dkk, Masjid Jami PITI Muhammad Cheng Hoo Purbalingga: Refleksi Akulturasi Budaya Pada Masyarakat Purbalingga, dalam Catharsis: Journal of Arts Education Volume 5 Nomor 2 2016, h.100

${ }^{11}$ Choirul Mahfud, The Role of Cheng Ho Mosque, The New Silk Road, Indonesia-China Relations in Islamic Cultural Identity, in Journal of Indonesian Islam Volume 8 Nomor 1 2014, h. 23-24

${ }^{12}$ Eka Srimulyani, et al., Diasporic Chinese Community in Post-Conflict Aceh. Socio-Cultural Identities and Social Relation with the Acehnese Muslim Majority, Al-Jami'ah, Journal of Islamic Studies Volume 56 Nomor 2 2018, h.398
} 
history, the da'wah movement was constantly faced with various challenges that hindered the da'wah movement itself. The Cheng Hoo Mosque, as one of the centers of the Islamic religious movement for the Chinese Muslim community in Makassar City, also plays a role in the da'wah movement. As a center of worship, Cheng Hoo Mosque in Makassar City carries out Islamic rituals and carries out da'wah activities aimed at all mosque congregations. Da'wah activities at the Cheng Hoo Mosque are manifested in the form of the implementation of worship in five daily prayers, Friday prayers, and tarawih prayers. Apart from that, Islamic study activities are regularly held by inviting preachers to study the Qur'an, hadith, fiqh, Islamic history, and various other themes. ${ }^{13}$

Apart from carrying out its da'wah activities, the Cheng Hoo Mosque also opens up to all organizations or all elements of Makassar City society who wish to use the Cheng Hoo Mosque as a place for carrying out religious activities. For the Cheng Hoo Mosque administrators, they want to show that the existence of this mosque is not only for the Chinese Muslim community but for all Muslims. As long as they obey the rules made by the mosque management, they are welcome to use the Cheng Hoo Mosque as a place for their da'wah activities. ${ }^{14}$

As one of the centers of da'wah activities in Makassar City, the da'wah challenges faced by the Cheng Hoo Mosque come from the reality of Makassar City as a multi-cultural city. The city is inhabited by diverse people in culture, economy, religion, and other social backgrounds. In specific contexts, the plurality of society can become a da'wah challenge if it cannot be adequately managed.

One aspect of plurality that can challenge da'wah comes from the reality of the Cheng Hoo Mosque itself, which is identical to the Chinese. In 1997 due to the provocation of irresponsible parties, the Chinese community in Makassar was once faced with racial sentiments. The people of Makassar City felt hatred very much for the Chinese, and there was looting, and destruction of places

\footnotetext{
${ }^{13} \mathrm{H}$. Suhardi, Founder of Cheng Hoo Mosque Tun Abd. Razak, Interview, 2 September 2020

${ }^{14} \mathrm{H}$. Suhardi, Founder of Cheng Hoo Mosque Tun Abd. Razak, Interview, 2 September 2020
} 
related to Chinese people. ${ }^{15}$ Regarding the incident, many analyzes describe the causes of this event. However, most argue that the domination of ethnic Chinese in the economic field in Makassar City gave birth to social jealousy, which led to this incident. ${ }^{16} \mathrm{~A}$ phenomenon like this is nothing new concerning the existence of Chinese people in Indonesia. ${ }^{17}$ Even though the condition is relatively not like it used to be, along with the rise of anti-Chinese sentiment lately, it is feared that this will affect the Cheng Hoo Mosque. It does not matter that this mosque is a symbol of Chinese Muslim identity.

Apart from racial sentiment, another plurality factor that is a challenge to da'wah for the Cheng Hoo Mosque is plurality among Muslims themselves. It cannot be denied that Islam as a religion stands on the diversity of its adherents, especially the diversity of understanding of Islam itself. In the aspect of worship, Muslims are divided into several mazhabs of fiqh. In addition, many religious organizations carry their characteristics in the diversity of the Islamic community, including in Makassar City. Various religious groups usually compete for influence among Muslims, including trying to seize strategic places where Muslims gather, such as mosques, intending to implement their religious practices in the mosque. Things like this are also a da'wah challenge for the Cheng Hoo Mosque.

Apart from plurality, another aspect that challenges the da'wah of the Cheng Hoo Mosque is the Islamic purification movement which tries to bring back the Islamic view as a transcendent, standard, unchanging, and eternal normative framework. This movement tries to change the religious behavior of the community, which is seen as deviating and no longer pure. Therefore, the Islamic puritanism movement seeks to bring Muslims to pure Islamic teachings based on the Al-Quran and the Hadith of the Prophet Muhammad. This movement seeks to correct various religious practices of the community which are deemed deviant and must be purified. Puritan Islam positions Islam as a

\footnotetext{
15Ratna Kustiaty dan Fenty Effendi, Agum Gumelar: jenderal bersenjata nurani (Jakarta, Pustaka Sinar Harapan: 2004) h.61-62

${ }^{16}$ Ratna Kustiaty dan Fenty Effendi, Agum Gumelar: jenderal bersenjata Nurani, h.78

${ }^{17}$ Laila Kholid Alfirdaus, Religion and anti-Chinese violence in Indonesian democratic transition $1997-$ 2004, dalam Jurnal Masyarakat, Kebudayaan, dan Politik Volume 28 Nomor 12015 h.23
} 
normative framework for transcendent, standard, unchanging, and eternal teachings. The building of laws and teachings must refer to the texts contained in the Qur'an and the Sunnah that implemented in Mecca and Medina as the geographical basis for the birth of Islam, without undergoing a process of historicization of teachings because the transcendent nature of the Qur'an and Sunnah is seen as not in contact with human culture at all. ${ }^{18}$

In Makassar, there was once a puritan Islamic group called Komite Persiapan Penegakan Syariah Islam - KPPSI (the Preparatory Committee for the Enforcement of Islamic Law), which was founded in 2000. This committee firmly stated its aspiration to pioneer the legally constitutional enforcement of Islamic law in South Sulawesi. ${ }^{19}$ Even though this organization's movement is no longer evident to the people of Makassar City, the influence of the ideology and thoughts that they instill has tended to spread to many individuals in Makassar City, including its preachers. The phenomenon of the purification of Islam, which always emphasizes returning to the Al-Quran and As-Sunnah today, has become a common theme widely discussed on social media due to information disclosure. Ideas about the purification of Islam are no longer dominated by local organizations such as KPPSI and the influence of transnational organizations with global networks such as ISIS or Al-Qaida.

For the Cheng Hoo Mosque, the presence of the Islamic puritan movement either individually or in an organized manner is a da'wah challenge in itself. Because the Cheng Hoo Mosque is currently seen as an icon of the Chinese Muslim movement that is quite influential in Makassar City, its existence has become the target of various religious groups or religious ideologies to serve as a place for the spread of certain religious understandings. This condition is of concern because the existence of the Cheng Hoo Mosque should not be identified with certain religious groups, and this will become an

\footnotetext{
18Umma Farida, Islam Pribumi dan Islam Puritan: Ikhtiar Menemukan Wajah Islam Indonesia Berdasar Proses Dialektika Pemeluknya dengan Tradisi Lokal, FIKRAH: Jurna Ilmu Aqidah dan Studi Keagamaan Volume 3 Nomor 1 Tahun 2015 h.146

${ }^{19}$ Bambang Karsono, Gerakan Radikal Islam di Sulawesi Selatan: Pola Rekrutmen dan Pola Gerakan Komite Persiapan Penegakan Syariat Islam (KPPSI) dan Laskar Jundullah, dalam Jurnal Keamanan Nasional Volime 4 Nomor 2 Tahun 2018, h. 234-235
} 
obstacle to the da'wah carried out by the Cheng Hoo Mosque in the multicultural existence of Makassar City.

\section{Multicultural Perspective as Way of Da'wah}

The Cheng Hoo Mosque has now positioned itself as an icon of the da'wah movement of Muslim Chinese in Makassar City, which is quite influential. With the characteristics of an unusual mosque, the Cheng Hoo Mosque provides a new discourse on da'wah's development in Makassar City. Cheng Hoo Mosque does not link its preaching activities only to Chinese Muslims but to all Muslims. The Cheng Hoo Mosque is also not labeled as the Nahdhatul Ulama (NU) mosque or the Muhammadiyah mosque, or any other Islamic group. This mosque has established itself as a mosque for all Muslims. ${ }^{20}$

The phenomenon of preaching at the Cheng Hoo Mosque is interesting because even though it has a Chinese Muslim identity, the da'wah activities at this mosque are open. Meanwhile, amidst the strengthening of the flow of group identity in religion, the Cheng Hoo Mosque freed itself entirely from religious group boundaries. The Cheng Hoo Mosque da'wah phenomenon can be a multi-cultural da'wah phenomenon that tends to enter all circles of Muslims without being limited by the barriers of religious, cultural, ethnic groups, and other social factors. The unifying factor is only one, namely Islam. Referring to the opinion of Ismail and Hotman about the indicators of multicultural da'wah ${ }^{21}$, there are at least three indicators of multicultural da'wah that can be found at the Cheng Hoo Mosque, namely:

1. Non-mazhab mosque

Cheng Hoo Mosque has a different policy from most mosques in carrying out da'wah activities to all groups. If in most mosques many associate their existence with a particular mazhab or religious sect that impacts the implementation of worship and various other religious statements in the mosque, then at Cheng Hoo Mosque, this will not be found. Cheng Hoo

\footnotetext{
${ }^{20}$ Agus Romdhoni, Imam of the Tanjung Bunga Metro Cheng Hoo Mosque, Interview, 4 September 2020

21 Ilyas Ismail dan Prio Hotman, Filsafat Dakwah, Rekayasa Membangun Agama dan Peradaban Islam (Jakarta: Kencana, 2011), h. 264-267
} 
Mosque, from its inception, was a mosque that was open to all Muslims and did not limit itself to any particular mazhab of thought. This is as revealed in the following statement:

"Cheng Hoo Mosque since its inception has established itself as a mosque that is open to all Muslims. The worship practices in this mosque all rely on the Al-Quran and the Sunnah of the Prophet Muhammad. We do not want Muslims to be divided according to certain mazhab of thought. So, this mosque became the mosque of all Muslims. The religious services and announcements carried out in this mosque are addressed to all people regardless of any mazhab or religious sect." 22

Th above statement shows the efforts of the Cheng Hoo Mosque to embrace all circles of Muslims without differentiating them based on certain mazhab of thought. Differences in religious practice based on certain mazhab of thought have sometimes become a source of division or khilafiyah among Muslims. Based on this, it can be understood that the Cheng Hoo Mosque defines itself as a mosque that does not incline to a particular religious sect.

Although it must be admitted that it is difficult to measure that the practice of worship and religious syiar is not identical with a particular mazhab or religious sect, from the claim that this mosque is not affiliated with a particular mazhab, this has become an indication that Cheng Hoo Mosque is trying to embrace all Muslims. Because it is realized that even though they come from one religion, Muslims have different religious orientations based on the religious school.

Cheng Hoo Mosque is open to all Muslims of any mazhab to carry out their activities in the mosque. All Muslims are welcome to enter the mosque to carry out various Islamic activities, even though it must comply with several rules set by mosque administrators, such as not discussing practical political issues, not carrying teachings that contain radicalism, and not opposing government policies. The rules are made for the convenience of all users of the Cheng Hoo Mosque. Managing the Cheng Hoo Mosque as a non-

${ }^{22}$ Agus Romdhoni, Imam of the Tanjung Bunga Metro Cheng Hoo Mosque, Interview, 4 September 2020 
sectarian mosque means that this mosque belongs to all Muslims and is not only a mosque for one mazhab. In this context, it can be seen that the nonmazhab policies implemented at the Cheng Hoo Mosque are a manifestation of da'wah in the context of multiculturalism.

2. The mosque is open to all groups.

The Cheng Hoo Mosque appears to represent a specific entity, namely the Chinese Muslim ethnicity, from naming and physical appearance. So that the possibility that some perceive that this mosque is exclusive to Chinese Muslims is not an exaggeration. However, in reality, the Cheng Hoo Mosque is a mosque that is not exclusive. This mosque is open to anyone and comes from any group. This policy at the Cheng Hoo Mosque is revealed in the following statement:

"Da'wah activities at the Cheng Hoo Tanjung Bunga Mosque are not only for Muslim Chinese citizens but are open to all Muslim citizens in Makassar. So, whoever they are, as long as they are Muslims, this mosque is open to becoming a place of worship and other religious activities. Cheng Hoo Mosque has the principle of being an inclusive mosque open to all and not a mosque that is exclusive to one group." 23

The above statement shows that the Cheng Hoo Mosque is a mosque that is open to all Muslims in Makassar City. There is no specificity only for certain groups. The Cheng Hoo Mosque policy, which is open to all groups of Muslims, is an effort to spread Islamic values to all circles is an attempt by the Cheng Hoo Mosque to actively participate as part of the global Muslim community for Islam rahmatan lil alamin. According to the mosque manager, several organizations such as NU and Muhammadiyah have held activities at the Cheng Hoo mosque. Likewise, student organizations from campuses such as HMI, PMII, IMM, and others have held activities at the Cheng Hoo Mosque. The effort to open ourselves apart from cultural barriers in spreading the values of Islamic teachings is an example of a multi-cultural da'wah at the Cheng Hoo Mosque.

${ }^{23}$ Olla Z. Pontoh, Management of the Cheng Hoo Metro Tanjung Bunga Mosque, Interview, 5 September 2020 
The effort to open the Cheng Hoo Mosque to all people cannot be separated from the history of the Cheng Hoo Mosque itself. Because in fact, the construction of a mosque embodied the participation of many parties, both cross-cultural and interfaith. This is reflected in the following statement:

"Our brothers from Chinese Muslims built this mosque because we Chinese Muslims have a container (Indonesian Chinese Islamic Association / PITI) and want to have a mosque that we plan to do as a place for preaching, to take part in the da'wah of Islam. However, in terms of financing, apart from coming from Muslim donors, it turns out that there is also funding assistance from non-Muslim Chinese donors."24

The above statement shows that from the very beginning, the Cheng Hoo Mosque had involved various Muslim and non-Muslim circles, Chinese and other ethnic groups who were united by one goal, namely establishing the Cheng Hoo Mosque. Thus, the policy of opening the Cheng Hoo Mosque to all groups is not a policy that just emerged, but since its inception, it has involved so many parties. The spirit of multiculturalism can be seen from the process of establishing the Cheng Hoo Mosque. Many parties set aside cultural differences and even differences in beliefs to create the Cheng Hoo Mosque. However, this mosque was founded on a multi-cultural spirit and therefore exists to nurture multiculturalism as a positive value in building a distinctive Islamic civilization in Makassar.

The Cheng Hoo Mosque's openness to all groups does not only apply to Muslims but also non-Muslims. Social relations at the Cheng Hoo Tanjung Bunga Mosque are built by cooperating with all parties, for example, with the FKUB. In this context, the Cheng Hoo Tanjung Bunga Mosque receives assistance from anyone, even non-Muslims.

In Ramadan, for example, the Cheng Hoo Mosque Takmirul received and facilitated the distribution of food aid from Buddhist donors. In order not to cause misunderstanding, the takmir committee who picked up the aid

${ }^{24}$ H. Suhardi, Founder of Cheng Hoo Mosque Jl. Tun Abdul Razak, Interview, 6 September 2020 
and the donors did not come to the Cheng Hoo Mosque. Even though it was distributed in the mosque, it was still conveyed the origin of the distributed aid. In the context of the Covid-19 Pandemic, Cheng Hoo Mosque also received assistance from non-Muslim sanitation facilities such as a barrel for washing hands. As long as it does not have a remarkable tendency, all assistance is accepted by the management of the Cheng Hoo Mosque is not exclusive in social relations. However, they also do not tolerate things that can damage these social relations.

3. Appreciation and acceptance of local culture

As a mosque that stands in the multi-cultural society, Cheng Hoo Mosque finds much cultural diversity in the community, especially the Bugis Makassar, including the religious culture that grows and develops in the people of Makassar City. Many religious understandings today echo the spirit of returning to the Al-Qur'an and Sunnah of the Prophet Muhammad, who tends to reject local culture into the religious aspect because it is seen as something that has no normative basis. On the other hand, Cheng Hoo Mosque accommodates local culture as part of the multi-cultural da'wah movement. This is as shown in the following statement:

"Concerning the local community's traditions, the Cheng Hoo Mosque is in principle open to the implementation of this tradition. The implementation of Maulid, Sinrili, Hadrah, as long as it does not contradict Islamic values, is welcome to be held at the Cheng Hoo Mosque. Because the management believes that it is the spirit behind this tradition that needs attention, not in its appearance. The point is that the substance of tradition as long as it does not conflict with Islam can be accepted at Cheng Hoo Mosque."25

Da'wah using local culture can be an alternative da'wah approach outside of the standard dakwah approach. Basically, all people of da'wah have cultural wealth according to the context of their locality. This cultural aspect can be used as a medium of preaching because many people can accept da'wah's delivery with a cultural approach.

250lla Z. Pontoh, Management of the Cheng Hoo Metro Tanjung Bunga Mosque, Interview, 5 September 2020 
The opening of the Cheng Hoo Mosque for the implementation of local religious traditions as long as it does not contradict the values of Islamic teachings and does not violate the rules set by the mosque management shows the awareness of the Cheng Hoo Mosque about the plurality of the people of Makassar City. With this awareness, the mosque manager accommodates the local culture of the Bugis Makassar community inside the Cheng Hoo Mosque, which ethnic Chinese Muslims characterize.

The description above shows three indicators that show the role of the Cheng Hoo Mosque in multi-cultural da'wah in Makassar City. These three idealizers play an essential role in carrying out da'wah from a multi-cultural perspective. Multi-cultural da'wah does not only tend to carry out da'wah alone but can also create harmonious relationships between the various cultures found in the da'wah field. The Cheng Hoo Mosque management policy that does not link the implementation of worship at the Cheng Hoo Mosque to certain mazhab is a strategic step to create a mosque that is open to all Muslims.

Another strategic step is a mosque open to all groups of cultures, ethnicities, and even interfaith groups. Because Cheng Hoo Mosque, since its inception, has involved many parties in it, both from Muslim and non-Muslim circles. The opening of the Cheng Hoo Mosque to all groups made it possible to build broad relationships with all groups to develop Islam itself. According to Parekh ${ }^{26}$, this is a description of how a culture cannot survive without the influence of other cultures beside it. One of the ways of developing Islam in Indonesia is due to the role of the Chinese Muslim community in Indonesia.

Acceptance and appreciation of local culture in various religious practices at Cheng Hoo Mosque shows that Cheng Hoo Mosque wants to build an attitude that worship is not only a matter of ritual but also involves social elements such as the customs and culture of the local community where the Cheng Hoo Mosque are located. Acceptance and respect for local culture is a tangible manifestation of the notion of multiculturalism itself. This

${ }^{26}$ Hendra Kurniawan, The Role of Chinese in Coming of Islam to Indonesia: Teaching Materials Development Based on Multiculturalism, in Paramita: Historical Studies Journal Volume 27 Nomor 2 2017, h. 247 
understanding tends to build a harmonious relationship within the frame of diversity. If this is played by a worship institution such as a mosque, this can be called a multi-cultural da'wah step. Moreover, this is practiced by the Cheng Hoo Mosque in the pluralistic society of Makassar City.

All descriptions of the da'wah movement at the Cheng Hoo Mosque, as stated above, show that the Cheng Hoo Mosque has played multi-cultural da'wah in the people of Makassar City. The role played by the Cheng Hoo Mosque in the multi-cultural da'wah movement is a manifestation of a long struggle to affirm their identity as part of the Muslim community in Makassar City amidst challenges that come from the plurality of society and Islamic purification movements, which sometimes lead to divisions among the Ummah. The multi-cultural da'wah approach has become a middle way concept of a plurality of society.

\section{E. Conclusion}

The Cheng Hoo Mosque, as a depiction of the identity of the Chinese Muslim community in Makassar City, has played an essential role in da'wah activities in a multi-cultural society. This dakwah approach is vital to be developed in a multi-cultural society in the midst of a multi-ethnic and multireligious society and awakening a spirit of religious purification, leading to social division. The multi-cultural da'wah movement played by the Cheng Hoo Mosque is carried out through three approaches, namely non-mazhab mosques, mosques that are open to all groups, cross-cultural and cross-faith, and acceptance and appreciation of local culture. All multi-cultural da'wah approaches carried out at the Cheng Hoo Mosque play a role in connecting multi-cultural societies, uniting various potentials to build an Islamic civilization. The multi-cultural da'wah activities at the Cheng Hoo Mosque have described the Chinese Muslim minority group playing an active role in the development of Islam in the majority Islamic community in Makassar City. 


\section{References}

Afif, Afthonul, Menjadi Indonesia: Pergulatan Identitas Tionghoa Muslim Indonesia, (Yogyakarta: Parikesit Institute, 2010)

Afriani, Dinda Wulan, Masjid Jami PITI Laksamana Muhammad Cheng Hoo Purbalingga: Simbol Keindahan Toleransi Dalam Akulturasi, IBDA Jurnal Kebudayaan Islam, 12 No. 1 (2014) p.27-39

Alfirdaus, Laila Kholid, Religion and anti-Chinese violence in Indonesian democratic transition 1997-2004, Jurnal Masyarakat, Kebudayaan, dan Politik, 28 No. 1 (2015) p.20-32

Alwajih, Ahmad, The Discourse of Tionghoa Muslim Identity in Indonesia After the Reform Order: A Critical Discourse Analysis of "Komunitas Cheng Hoo" Magazine, Asian Journal of Media and Communication, 4 No. 2 (2020) p.99110

Blum, Lawrence, dan Dwicipta, dalam Andre Ata Ujan Ph.D., Multikulturalisme Belajar Hidup Bersama dalam Perbedaan (Jakarta: PT. INDEKS, 2011)

Ismail, Ilyas, Hotman, Prio, Filsafat Dakwah, Rekayasa Membangun Agama dan Peradaban Islam (Jakarta: Kencana, 2011),

Izzuddin, Fata, Ahmad Kairul, Realizing Religion as The Source of Harmony in a Multi-cultural Society, Kontemplasi: Jurnal Ilmu-ilmu Ushuluddin, 8(02) 2020

Juliani, Reni, Cangara, Hafied, Unde, Andi Alimuddin, Komunikasi Antar Budaya Etnis Aceh dan Bugis-Makassar Melalui Asimilasi Perkawinan di Kota Makassar, Jurnal Komunikasi KAREBA,4 No. 1 (2015) p.70-87

Karsono, Bambang, Gerakan Radikal Islam di Sulawesi Selatan: Pola Rekrutmen dan Pola Gerakan Komite Persiapan Penegakan Syariat Islam (KPPSI) dan Laskar Jundullah, Jurnal Keamanan Nasional, 4 No. 2 (2018) p.231-246

Kurniawan, Hendra, The Role of Chinese in Coming of Islam to Indonesia: Teaching Materials Development Based on Multiculturalism, Paramita: Historical Studies Journal. 27 No. 2 (2017) DOI: 10.15294/paramita.v27i2.8660

Kustiaty, Ratna, dan Effendi, Fenty, Agum Gumelar: jenderal bersenjata nurani (Jakarta, Pustaka Sinar Harapan: 2004)

Mahfud, Choirul, Chinese Muslim Community Development in Contemporary Indonesia: Experiences of PITI in East Java, Studia Islamika, 25 No. 3 (2018) DOI:10.15408/sdi.v25i3.6755 
Mahfud, Choirul, The Role of Cheng Ho Mosque, The New Silk Road, IndonesiaChina Relations in Islamic Cultural Identity, Journal of Indonesian Islam, 8 No. 1 (2014) DOI:10.15642/JIIS.2014.8.1.23-38

Rahmawati, et al., Chinese Ways Being a Good Muslim: From The Cheng Hoo Mosque to Islamic Education and Media Literacy, Indonesian Journal of Islam and Muslim Societies (IJIMS), 8 No. 2 (2018) DOI:10.18326/ijims.v8i2.225-252

Rizky, Amanda, Re-Aktualisasi Kisah Perjalanan Laksamana Cheng Hoo di Cirebon Melalui Batik (Kajian Batik di Cirebon serta hubungannya dengan Bahasa Rupa Tradisi, CORAK Jurnal Seni Kriya, 8 No. 1 (2019) DOI: https://doi.org/10.24821/corak.v8i1.2688

Srimulyani, Eka, et al., Diasporic Chinese Community in Post-Conflict Aceh. SocioCultural Identities and Social Relation with the Acehnese Muslim Majority, Al-Jami'ah, Journal of Islamic Studies, 56 No. 2 (2018) DOI:10.14421/ajis.2018.562.395-420

Yunariono, Bastian, Andriati, Retno, The Construction of Chinese Muslims Identities in Surabaya, Walisongo: Jurnal Penelitian Sosial Keagamaan, 28 No. 1 (2020) DOI:10.21580/ws.28.1.6264 